\title{
TRENDS IN INFORMATION TECHNOLOGY PROJECT MANAGEMENT
}

\author{
Rosarito Sánchez-Morcilio, University of Puerto Rico, Río Piedras Campus, rosarito.sanchez@upr.edu \\ Francisco Quiles-Torres, University of Puerto Rico, Río Piedras Campus, francisco.quiles@upr.edu
}

\begin{abstract}
Project management is used in all organizations to deliver key initiatives in support of the operational goals. Information Technology plays a vital role in today's global environment. Project managers must be competent in order to deliver Information Technology projects effectively. This article presents a qualitative research of recent (2014-2016) peer review journals in the area of Information Technology project management. Knowledge areas and key success factors, as defined by the Project Management Institute, are identified and qualified. The results provide valuable insight information on what are the key areas that Information Technology project managers must focus to be effective in delivering projects, as well as recommendations for future research.
\end{abstract}

Keywords: Project Management (PM), Information Technology (IT), Trends, Operations, Information Systems (IS)

\section{INTRODUCTION}

Information Technology (IT) is crucial in today's economy as large financial and business transactions are made every day, which require robust systems to support them, thus leading to substantial investment on IT systems (Gingnell, Franke, Lagerström, Ericsson, Lilliesköld, 2014). Since business initiatives, such as IT infrastructure enhancements, are implemented through projects, IT projects contribute to the success of the entire business (Tuzcu, \& Esatoglu, 2011) by improving its operation (Jacobs, \& Chase, 2010). Urli \& Urli Project Management (PM) study, explained by Obeidat \& North 2014, revealed most projects in organizations $(63 \%)$ are related to IT, followed by research and development (24\%) and general construction (13\%). A Project Management Institute (PMI) study, as explained by Capterra 2015, affirmed there will be fifteen million new project management jobs within the next decade. Recent studies on the performance of IT projects had indicated that many fail in delivering the expected deliverables on time and on budget. A study by Standish Group found that just 32\% of all projects were completed on time and on budget over the past year; $44 \%$ of the projects were completed without fullfilling all the deliverables and 24\% failed completely (Standish, 2009, Capterra, 2015, Fulk, Kwun, \& Alijani, 2013, Holgeid, \& Thompson, 2013). Capterra 2015 indicated that the results of various studies pointed towards the need to improve the PM skills of the project managers: A Harvard Business Review study showed that $17 \%$ of the IT projects had an average cost overrun of $200 \%$ while a Geneca study concluded that IT projects had an average schedule overun of $70 \%$. In addition, Capterra 2015 highlighted the fact that Wrike study showed that only $56 \%$ of the IT project managers were certified by PMI as Project Management Professionals (PMP), which tends to indicate that many project managers on the field may be lacking formal education in the PM area. Wrike study also indicated that high-performing organizations successfully completed $89 \%$ of their projects, while low performers completed only $36 \%$ of their projects. Similary, Capterra 2015 mentioned, according to the PM Solutions study, that only $49 \%$ of organizations have project management training in place. IT projects are important not only in the private sector, but also in the government as well. For example, the State of Conneticut, a high performer in managing IT projects, had managed seventy-two projects with a budget in excess of two hundred million dollars, over the last decade, with an average project completion of two years (Data Catalog, 2016). Currently, $74 \%$ of their projects, which required $95 \%$ of the total budget, are in the "post implementation" phase and on track on budget, schedule and deliverables. This article outlines the success factors to manage IT projects effectively, which will help the organization achieve their business goals. 


\section{Definitions}

\section{BACKGROUND}

Information Technology (IT) is defined by the Business Dictionary 2016 as a collection of tools, processes, and methodologies (such as coding / programming, data communications, data conversion, storage and retrieval, systems analysis and design, systems control) and associated equipment employed to collect, process, and present information. It includes automation, multimedia, and telecommunications. In short, IT is the use of software, hardware, and communication to process data in the organization.

Project Management (PM) is defined by Project Management Institute (PMI) 2016 as a temporary effort striven for creating a unique or distintive product, service or result. Gray \& Larson 2009 defined PM as a complex effort, designed to comply a client's needs, which is uncommon, limited by time, budget, resources, and scope. As for this study's definition, PM is a short-lived venture, limited by time, budget, resources, and scope, to create a unique product or service according to the client's requirements. Given those explanations, Information Technology Project Management (IT PM) can be defined as a brief undertaking, limited by time, budget, resources, and scope, to develop tools, including software, hardware, and communication, to process data in the organization according to client's expectations.

Trends, as a noun, is defined by the Merriam-Webster 2016, as a prevaling or general movement or inclination. It implies direction, current, tendency, drift, and propensity. Thus, trends in information technology project management represent the key areas that IT project managers must focus to be effective in delivering projects.

\section{Importance of IT}

After construction, the second industry traditionally associated with project management is IT (Spalek, 2014). From the business standpoint, IT PM and PM in general, are key for the success of the every day operations of an organization (Jacobs, \& Chase, 2010). On the private sector, strong operations generate more profit for each dollar of sale, thus making the organization attractive to investors. From the economy standpoint, IT has emerged as one of the fastest growing industries in many countries as it sets the pattern of the internationalization of organizations to better participate in the global economy (Paul \& Gupta, 2014). Dutta, Geiger, \& Lanvin 2015 explained IT, more especifically the Information and Communication Technologies (ICTs), is a vector of social development and transformation by improving access to basic services, enhancing connectivity, and creating employment opportunities. The ICTs, as the authors mentioned, transform economies, and accelerates the pace of innovation, which allow addressing situations such as poverty, unemployment, and lack of access to quality education. IT sector promotes growth and prosperity to countries. Moreover, Dutta, Geiger, \& Lanvin 2015 developed a Networked Readiness Index (NRI) 2015 table, which provides ranking data for 143 countries. The NRI a composite indicator that includes technology, economic, and social pillars of a country and shows each country's income level per cápita; higher values of NRI equates higher income levels. For example, the table shows that Singapore, an island in southern Malaysia, has the highest NRI as well as an elevated income per cápita while Chad, a country in northern central Africa, has the lowest NRI value as well as a small income level. Their report offer many solutions and examples of policies and investments to help countries to better leverage ICTs for a shared prosperity.

\section{Main Contribution of the Article}

IT PM, and PM, in general, characterize strategic accomplishments for the regular operations of a company (Jacobs, $\&$ Chase, 2010). Thus, the better IT projects are managed by the organizations of a country, the higher positive impact in its economic prosperity (Dutta, Geiger, \& Lanvin, 2015). The main contribution of this study is to provide the current trends in the IT PM, which must be emphazised to improve the effective management of projects. Trends are based on the association of the PMI's knowledge areas (PMBOK®: PMI, 2013) to the IT PM key success factors found in literature. This article outlines valuable information concerning the set of factors to manage IT projects sucessfully, which has great relevance to academia, students and business executives. The results of this study are relevant since it provides the key areas within PM that need to be emphasized to sucessfully manage IT projects on the current organizational atmosphere. The research question stated was: "what are the latest IT PM trends?" 


\section{RESEARCH METHODOLOGY}

This is a qualitative research article based on formal review of literature. An analysis of a diverse, yet carefully selected, recently published peer-reviewed journals articles provided enough material to find the IT PM trends. The articles were found in EbscoHost database under the search key words "information technology" and "project management" from 2014 to present (2016). The key success factors highlighted by the authors to effectively manage IT projects were tabulated, abbreviated into 1-2 words short phrases and then associated to the PMI's knowledge areas

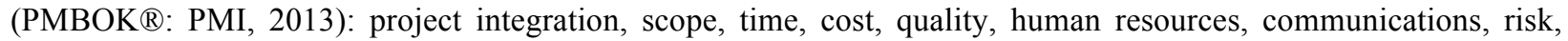
procurement, and shareholder management. Those associations were considered to be trends in the IT PM field for this study. Microsoft Access ${ }^{\circledR}$ was used for the classification of the key success factors. Figure 1: Key Success Factor (KSF) Form shows the form used to classify the key success factors name, KSF element, its authors to the knowledge area (PMBOK $\AA$ : PMI, 2013). Once all input data was entered, two reports were generated. Figure 2: Key Success Factors Partial View Report shows a partial view of the first report, which lists the key success factors name, key success factors element, its authors, and the knowledge area (PMBOK®: PMI, 2013).

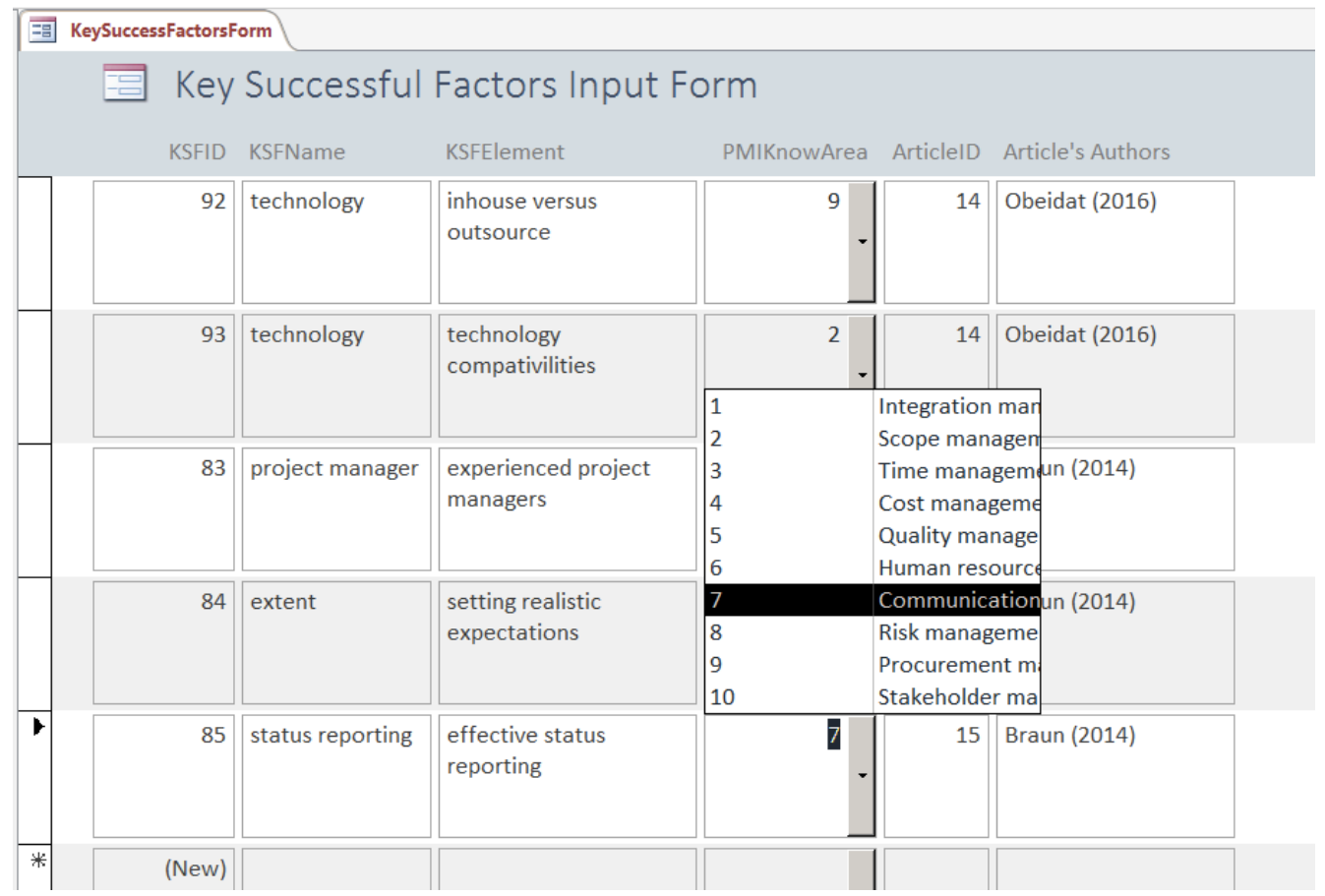

Figure 1. Key Success Factors (KSF) Input Form 
Issues in Information Systems

Volume 17, Issue III, pp. 187-198, 2016

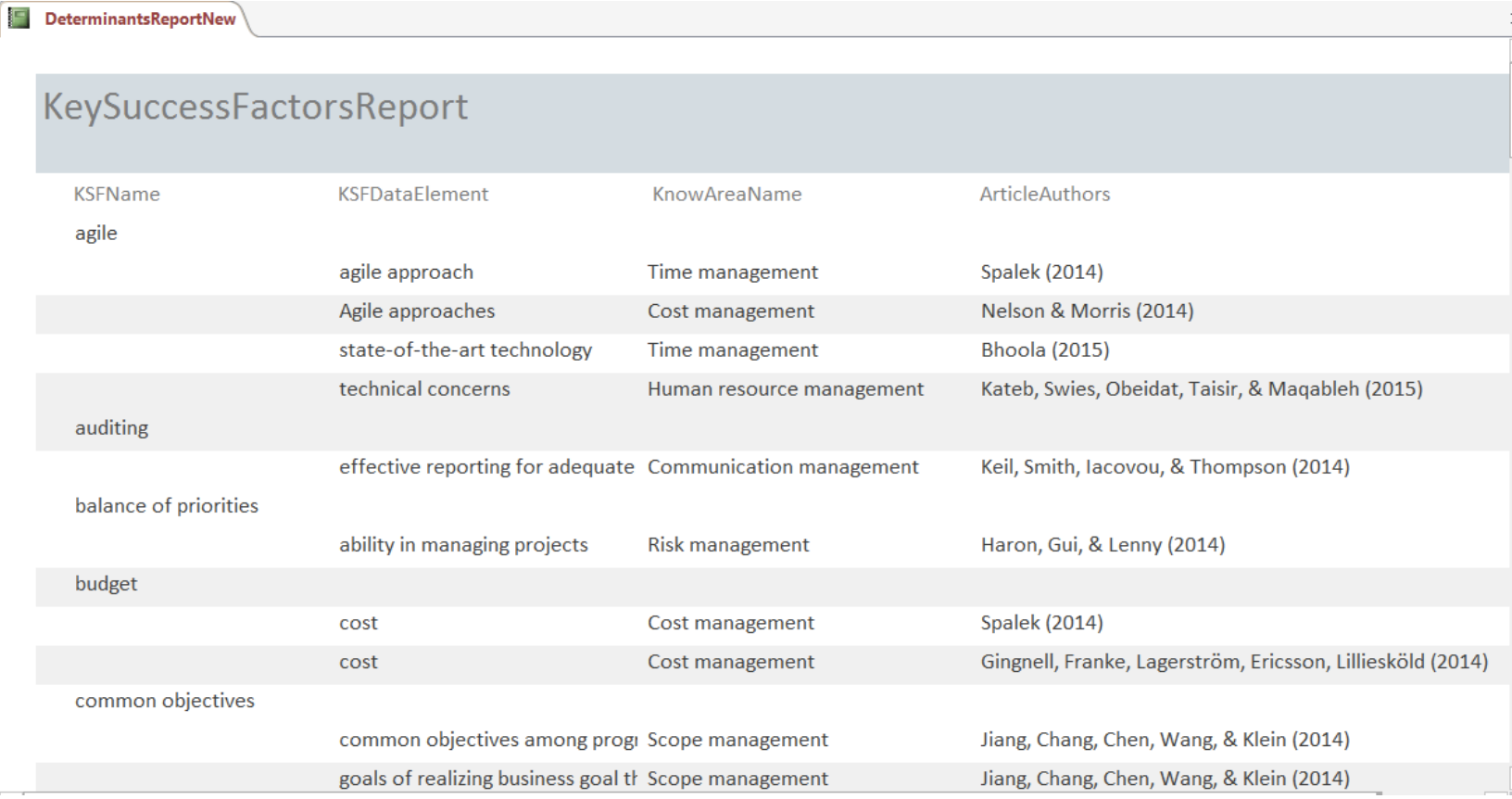

Figure 2. Key Success Factors (KSF) Partial View Report

The second report is shown in Tables $\mathbf{1}$ and $\mathbf{2}$. 
Table 1. Trends: "Knowledge Areas (PMBOK®: PMI, 2013)" with its associated "Key Success Factor (KSF)" and its corresponding authors.

Part I

\begin{tabular}{|c|c|c|}
\hline 1 & & Communication management (PMBOK®: PMI, 2013) \\
\hline \multirow{11}{*}{$\frac{5}{2}$} & auditing & Keil, Smith, Iacovou, \& Thompson (2014) \\
\hline & communication & $\begin{array}{l}\text { Mastrogiacomo, Missonier, \& Bonazzi (2014), Wilfong (2014), Haron, Gui, \& Lenny } \\
\text { (2014) }\end{array}$ \\
\hline & competencies & Bhoola (2015) \\
\hline & conflict resolution & Jiang, Chang, Chen, Wang, \& Klein (2014) \\
\hline & environment & Bhoola (2015) \\
\hline & intention & Mastrogiacomo, Missonier, \& Bonazzi (2014) \\
\hline & language & Mastrogiacomo, Missonier, \& Bonazzi (2014) \\
\hline & status reporting & Keil, Smith, Iacovou, \& Thompson (2014), Braun (2014) \\
\hline & technology & Wilfong (2014) \\
\hline & time & Mastrogiacomo, Missonier, \& Bonazzi (2014) \\
\hline & trust & Keil, Smith, Iacovou, \& Thompson (2014) \\
\hline 2 & & Cost management (PMBOK®: PMI, 2013) \\
\hline \multirow{5}{*}{$\frac{1}{2}$} & agile & Nelson \& Morris (2014) \\
\hline & budget & Gingnell, Franke, Lagerström, Ericsson, Lilliesköld (2014), Spalek (2014) \\
\hline & estimation & Nelson \& Morris (2014), Cârstea (2014) \\
\hline & retrospectives & Nelson \& Morris (2014) \\
\hline & technology & Nelson \& Morris (2014) \\
\hline 3 & & Human resource management (PMBOK®: PMI, 2013) \\
\hline \multirow{15}{*}{$\frac{1}{\sqrt{2}}$} & agile & Kateb, Swies, Obeidat, Taisir, \& Maqableh (2015) \\
\hline & competencies & Rivera-Ruiz \& Ferrer-Moreno (2015) \\
\hline & human resources & Rivera-Ruiz \& Ferrer-Moreno (2015), Spalek (2014) \\
\hline & integrity & Haron, Gui, \& Lenny (2014) \\
\hline & leadership & $\begin{array}{l}\text { Wilfong (2014), Bhoola (2015), Rivera-Ruiz \& Ferrer-Moreno (2015), Haron, Gui, \& Len- } \\
\text { ny (2014) }\end{array}$ \\
\hline & listening & Haron, Gui, \& Lenny (2014) \\
\hline & organizational behavior & Wilfong (2014) \\
\hline & policies & Bhoola (2015) \\
\hline & project manager & $\begin{array}{l}\text { Haron, Gui, \& Lenny (2014), Kateb, Swies, Obeidat, Taisir, \& Maqableh (2015), Cârstea } \\
\text { (2014), Nelson \& Morris (2014), Rivera-Ruiz \& Ferrer-Moreno (2015), Braun (2014) }\end{array}$ \\
\hline & quality & Haron, Gui, \& Lenny (2014) \\
\hline & reward structure & Bhoola (2015) \\
\hline & support & Wilfong (2014) \\
\hline & teamwork & Mastrogiacomo, Missonier, \& Bonazzi (2014), Nelson \& Morris (2014) \\
\hline & technology & Wilfong (2014) \\
\hline & trust & Haron, Gui, \& Lenny (2014) \\
\hline
\end{tabular}


Table 2. Trends: "Knowledge Areas (PMBOK®: PMI, 2013)" with its associated "Key Success Factor (KSF)" and its corresponding authors.

\section{Part II}

\begin{tabular}{|c|c|c|}
\hline 4 & & Integration management (PMBOK®: PMI, 2013) \\
\hline \multirow{9}{*}{$\frac{5}{2}$} & control & Cârstea (2014) \\
\hline & coordination & Mastrogiacomo, Missonier, \& Bonazzi (2014) \\
\hline & decision process & Mastrogiacomo, Missonier, \& Bonazzi (2014) \\
\hline & environment & Spalek (2014) \\
\hline & lessons learned & Bhoola (2015) \\
\hline & minimal customization & Kateb, Swies, Obeidat, Taisir, \& Maqableh (2015) \\
\hline & planning & Bhoola (2015) \\
\hline & processes & Wilfong (2014), Bhoola (2015) \\
\hline & unique conditions & Jiang, Chang, Chen, Wang, \& Klein (2014) \\
\hline 5 & \multicolumn{2}{|r|}{ Procurement management (PMBOK®: PMI, 2013) } \\
\hline$\frac{5}{\sqrt{n}}$ & technology & Obeidat (2016) \\
\hline 6 & \multicolumn{2}{|r|}{ Quality management (PMBOK®: PMI, 2013) } \\
\hline \multirow{3}{*}{$\sqrt{2}$} & product quality & Kateb, Swies, Obeidat, Taisir, \& Maqableh (2015) \\
\hline & quality & Gingnell, Franke, Lagerström, Ericsson, Lilliesköld (2014), Cârstea (2014) \\
\hline & regulations & Kateb, Swies, Obeidat, Taisir, \& Maqableh (2015) \\
\hline 7 & \multicolumn{2}{|r|}{ Risk management (PMBOK®: PMI, 2013) } \\
\hline \multirow{4}{*}{$\frac{5}{2}$} & balance of priorities & Haron, Gui, \& Lenny (2014) \\
\hline & conflict resolution & Haron, Gui, \& Lenny (2014) \\
\hline & problem solving & Haron, Gui, \& Lenny (2014) \\
\hline & risk & Cârstea (2014) \\
\hline 8 & \multicolumn{2}{|r|}{ Scope management (PMBOK®: PMI, 2013) } \\
\hline \multirow{6}{*}{$\frac{1}{2}$} & common objectives & Jiang, Chang, Chen, Wang, \& Klein (2014), Cârstea (2014) \\
\hline & conflict resolution & Jiang, Chang, Chen, Wang, \& Klein (2014) \\
\hline & control & Cârstea (2014) \\
\hline & extent & Bhoola (2015), Spalek (2014), Braun (2014) \\
\hline & teamwork & Jiang, Chang, Chen, Wang, \& Klein (2014) \\
\hline & technology & Obeidat (2016) \\
\hline 9 & \multicolumn{2}{|r|}{ Stakeholder management (PMBOK®: PMI, 2013) } \\
\hline \multirow{3}{*}{$\frac{1}{2}$} & communication & Kateb, Swies, Obeidat, Taisir, \& Maqableh (2015) \\
\hline & support & Haron, Gui, \& Lenny (2014) \\
\hline & trust & Keil, Smith, Iacovou, \& Thompson (2014) \\
\hline 10 & \multicolumn{2}{|r|}{ Time management (PMBOK®: PMI, 2013) } \\
\hline & agile & Bhoola (2015), Spalek (2014) \\
\hline$\overline{\tilde{v}}$ & time & $\begin{array}{l}\text { Bhoola (2015), Gingnell, Franke, Lagerström, Ericsson, Lilliesköld (2014), Spalek (2014), } \\
\text { Cârstea (2014) }\end{array}$ \\
\hline
\end{tabular}




\section{FINDINGS}

A total of fifty-seven articles were found on the EbscoHost database by using the previously described search criteria, from which fifteen were selected as were deemed appropriate for the research question. One of the fifteen articles was discarded since, although very informative, it did not focus on the overall IT project management perspective. From the remaining fourteen articles, four were considered both qualitative and quantitative in nature, while seven were quantitative and four were qualitative. All fourteen articles presented studies in the IT area. One of the articles showed construction and machinery areas, in addition to IT. But since that article presented data by area, we could extract IT data the study. Five articles were related to the United States (USA), four to Europe, three to Asia, one to the Middle East and one to the Caribbean. Only one article specified its study was conducted using data from the public sector. A total of ninety-three key success factors were extracted from the fourteen articles, from which forty-one were different. The results of this study are shown in Tables 1 and 2: Trends: "Knowledge Areas (PMBOK®: PMI, 2013)" with its associated "Key Success Factor (KSF)" and its corresponding authors. Figure 3: Pictorial View of Information Technology Project Management Trends summarizes data from both tables.

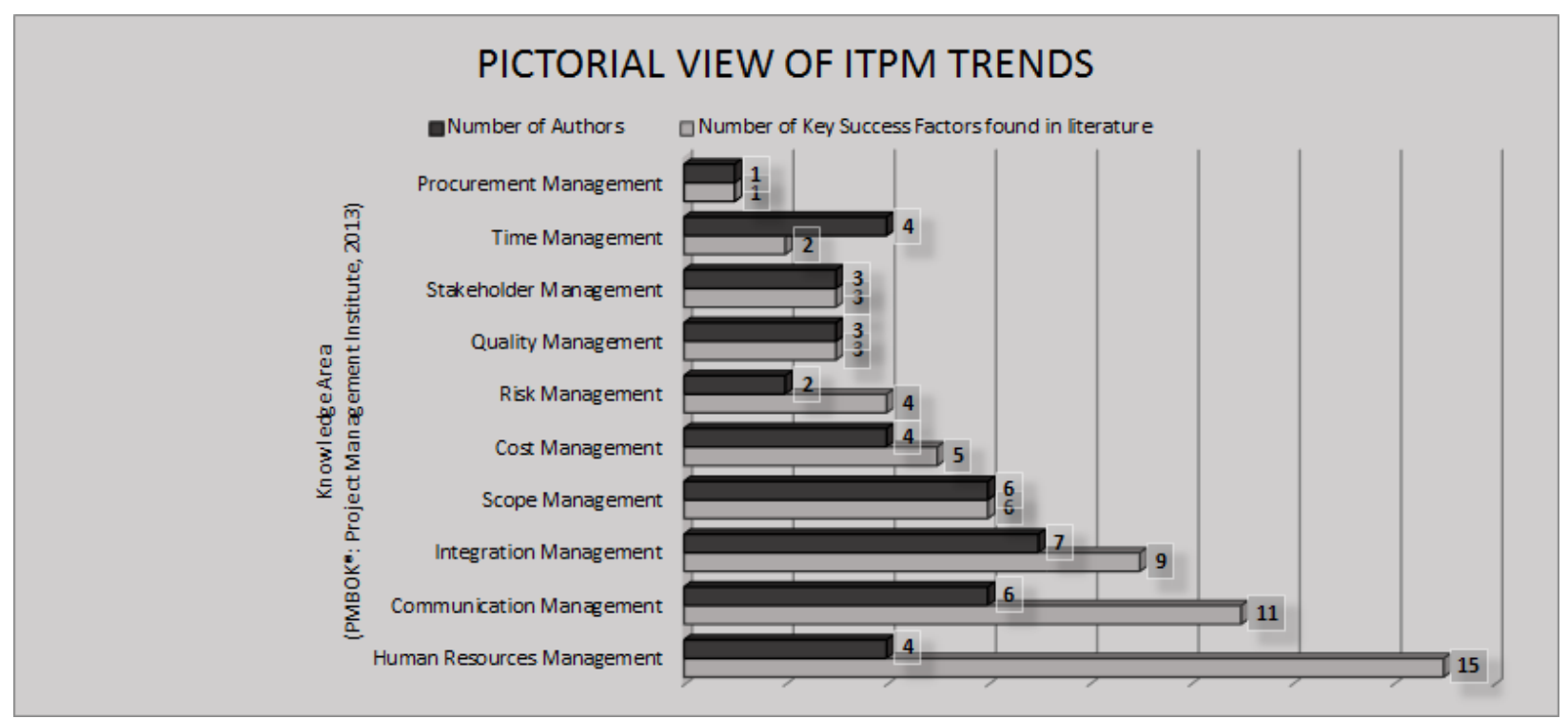

Figure 3. Pictorial View of Information Technology Project Management (IT PM) Trends

\section{DISCUSSION}

According to PMI (PMBOK®): PMI, 2013), all knowledge areas are equally important. Key success factors associated to each knowledge area are presented as the IT PM trends. IT PM trends are relevant since those provide the key areas that need to be emphasized to successfully manage IT projects. The trends developed in this study are shown in Tables 1 and 2.

Human resources management knowledge area, (PMBOK $\AA$ : PMI, 2013), was attributed to the most number of key success factors in managing IT projects, according to four of the articles (Bhoola, 2015, Spalek, 2014, Gingnell, Franke, Lagerström, Ericsson, Lilliesköld, 2014, and Cârstea, 2014). It was associated to agile, competencies, human resources, integrity, leadership, listening, organizational behavior, policies, project manager, quality, reward structure, support, teamwork, technology, and trust. The human resources management aspect is often overlooked, but the importance of team productivity, leadership, effective listening, willingness to demonstrate a good relationship with others, responsiveness to the demanding tasks, integrity in conducting activities, and the sharing of knowledge with coworkers are key to the success of an IT project (Bhoola, 2015, Spalek, 2014, Gingnell et al., 
2014, and Cârstea, 2014). IT project managers, in particular, must show correctness, in his / her performance, to achieve trust from the organization, and the ability to work with all the peculiarities of an IT project (Haron, Gui, \& Lenny, 2014). IT project managers must keep acquiring field experience and knowledge to better handle future IT projects. It is recommended that the Human Resources division must support its personnel by offering them relevant trainings, as well as flexible policies leading to a good live work balance, attractive salaries and rewards so that the organization can attract and retain good and experienced IT project managers (Bhoola, 2015). It is also important that the company's hiring policies provide the flexibility to quickly recruit personnel in support of the project needs (Nelson, \& Morris, 2014).

Communication management knowledge area, (PMBOK ${ }^{\circ}$ : PMI, 2013), was attributed to be the second of the key success factors by Keil, Smith, Iacovou, \& Thompson (2014), Mastrogiacomo, Missonier, \& Bonazzi (2014), Wilfong (2014), Haron, Gui, \& Lenny (2014), Bhoola (2015) and Jiang, Chang, Chen, Wang, \& Klein (2014). It relates to auditing, communication, competencies, conflict resolution, environment, intention, language, status reporting, technology, time, and trust. Effective reporting can improve trust between IT project members as well as its every stakeholder, as Keil et al. (2014) explained. Auditing processes, and the conflict resolution would run smoothly if timely IT projects status reports are provided, as Keil et al. (2014) and Jiang et al. (2014) stated. Also, healthy communication delivers a good IT PM environment to deal with every day challenges (Bhoola, 2015). Effective communication, both written and verbal, within the team members, including the IT project leader and other stakeholders, is key to promote a good working environment (Mastrogiacomo, Missonier, \& Bonazzi, 2014).

Integration management knowledge area, (PMBOK ${ }^{\circ}$ : PMI, 2013), relates to control, coordination, decision process, environment, lessons learned, minimal customization, planning, processes, and unique conditions. Cârstea (2014), Mastrogiacomo, Missonier, \& Bonazzi (2014), Spalek (2014), Bhoola (2015), Kateb, Swies, Obeidat, Taisir, \& Maqableh (2015), Wilfong (2014) and Jiang et al. (2014) proposed those key success factors as important. IT project leaders must demonstrate their ability to manage conflict by making the necessary adjustments to the project plans quickly so that the project remains on course. The IT project leader must coordinate so that all the different projects within a program respond to the business goals (Mastrogiacomo, Missonier, \& Bonazzi, 2014). Some authors (Spalek, 2014, and Jiang et al., 2014) suggested that IT projects have unique conditions that may require flexibility during the planning process, while others (Kateb et al., 2015) indicated that minimal customization is recommended. Every IT project must follow a plan that includes process guidelines, and well-followed processes (Bhoola, 2015). Lastly, when the IT project is completed, lessons learned must be discussed among all IT project members as a way to develop knowledge for future projects (Bhoola, 2015).

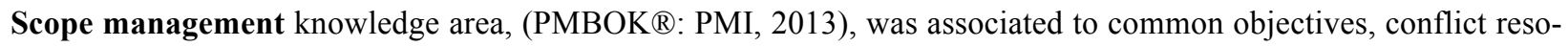
lution, control, extent, teamwork, and technology, according to Jiang et al. (2014), Cârstea (2014), Bhoola (2015), Spalek (2014), Braun (2014), and Obeidat (2016). When developing the scope management plans, it is important to take into consideration the common objectives of the program, which is constituted by a group of projects (Jiang et al., 2014). An IT project cannot be planned in isolation from the ongoing operations or in conflict with other projects being executed in parallel; it is imperative to ensure technical compatibilities among projects in any organization (Jiang et al., 2014, Bhoola, 2015, Spalek, 2014, and Braun, 2014). An IT project must possess the adequate controls to comply with security among the business events, data, and information, as well as the software requirements, and the technology competitiveness (Cârstea, 2014). Lastly, all members in the IT project team must work toward reasonable customer expectations (Bhoola, 2015, Spalek, 2014, and Braun, 2014).

Cost management knowledge area, (PMBOK®: PMI, 2013), was connected to agile, budget, estimation, retrospectives, and technology, as explained by Nelson \& Morris (2014), Gingnell et al. (2014), Spalek (2014), and Cârstea (2014). It is suggested to use agile approaches, as well as tools such as Microsoft Project and Excel, to better estimate the IT project budget. It is also recommended to study the project retrospectives and lessons learned, as soon as the project is completed, to build knowledge so that better estimations can be determined in the future (Nelson \& Morris, 2014).

Risk management knowledge area, (PMBOK $®$ : PMI, 2013), was linked to balance of priorities, conflict resolution, problem solving, and risk by Haron, Gui, \& Lenny (2014), and Cârstea (2014). Those authors suggest a balance of priorities, to manage the risk for the IT project. In addition, problem solving and conflict resolution are great quali- 
ties an IT project manager must demonstrate to effectively deal with the jeopardy that may be associated to an IT project (Haron, Gui, \& Lenny, 2014).

Quality management knowledge area, (PMBOK®: PMI, 2013), was interrelated to product quality and compliance with applicable regulations. The IT product to be delivered by the project must comply with the user requirements, as well as all applicable regulations, according to Kateb et al. (2015), Gingnell et al. (2014), and Cârstea (2014).

Stakeholder management knowledge area, (PMBOK®: PMI, 2013), was associated to communication, support, and trust by Kateb et al. (2015), Haron, Gui, \& Lenny (2014), and Keil et al. (2014). Those authors specified that an IT project manager will gain trust and support from the stakeholders, especially senior management, as long as effective communication of the IT project status is supplied and issues are escalated on a timely matter for their resolution.

Time management knowledge area, (PMBOK ${ }^{\circledR}$ : PMI, 2013), was associated to being agile and aggressively manage time by Bhoola (2015), Spalek (2014), Gingnell et al. (2014), and Cârstea (2014). Those authors explained state-of-the art technology and agile iteration techniques are advised for an improved time control and delivery of an IT project.

Procurement management knowledge area, (PMBOK®: PMI, 2013), was associated to just one key success factor, technology (Obeidat, 2016). When managing an IT project, especially during the planning phase, careful discerning, between developing software and its overall technology in house versus outsource, is advised by the author.

Figure 1 (Pictorial View of Information Technology Project Management Trends) presents a summary from Tables 1 and 2. For example, there is one author describing one key success factor for the procurement management knowledge area (PMBOK ${ }^{\circledR}$, PMI, 2013), while there are four authors explaining fifteen key success factors for the human resource management knowledge area (PMBOK ${ }^{\circledR}$, PMI, 2013).

\section{Conclusion}

Project management (PM) is crucial for the success of the organization's operations (Jacobs, \& Chase, 2010). Thus, the better IT projects are managed, the higher the achievements for the organization. Trends in IT PM were identified by matching each PMI knowledge area, (PMBOK®: PMI, 2013), to the key success factors suggested from contemporary literature. The results illustrated the recommendations for effective management of Information Technology (IT) projects. The main contribution of this article to academia is to show the key areas within PM that need to be emphasized to successfully manage IT projects. The following fifteen recommendations summarize the leading trends in IT PM at any organization:

1- Agile approaches as a key success factors for managing IT projects was related to three different knowledge areas, (PMBOK®: PMI, 2013): time, cost, and human resource management (Spalek, 2014, Nelson \& Morris, 2014, Bhoola, 2015, Kateb et al., 2015).

2- Effective reporting of the IT project status is advised for adequate auditing (Keil et al., 2014).

3- Regular IT project status reports help gaining trust among stakeholders and top management (Keil et al., 2014, and Braun, 2014).

4- Balance of the IT project priorities are recommended to deal with risk (Haron, Gui, \& Lenny, 2014).

5- Common objectives and timely conflict resolutions between the IT program managers, a group of IT projects, and the actual operation personnel are recommended for the success of the IT projects in an organization (Haron, Gui, \& Lenny, 2014, Jiang et al., 2014, and Cârstea, 2014). 
6- A healthy relationship between those parties also help solving technical compatibly issues that may arise from a new project (Obeidat, 2016, Keil et al., 2014, Mastrogiacomo, Missonier, \& Bonazzi, 2014, Wilfong, 2014, Haron, Gui, \& Lenny, 2014, Bhoola, 2015, and Jiang et al., 2014).

7- IT project environment must promote integration and effective communication, as explained by Keil et al. (2014), Mastrogiacomo, Missonier, \& Bonazzi (2014), Wilfong (2014), Haron, Gui, \& Lenny (2014), Bhoola (2015), and Jiang et al. (2014).

8- Clear language, active listening, and transparent communications from individuals are three elements found in effective communication (Mastrogiacomo, Missonier, \& Bonazzi, 2014).

9- IT project scope must set reasonable customer expectations (Bhoola, 2015, Spalek, 2014, and Braun, 2014).

10- IT project must deliver a quality product, meeting its user requirements and all applicable regulations (Kateb et al., 2015, Gingnell et al., 2014, and Cârstea, 2014).

11- Each IT project has unique conditions that may arise after planning (Kateb et al., 2015, Gingnell et al., 2014, and Cârstea, 2014).

12- IT project manager must provide sufficient controls for a timely delivery (Cârstea, 2014, Bhoola, 2015, Gingnell et al., 2014, and Spalek, 2014).

13- IT projects technological aspects must include a centralized system of resources, software requirements versus technological compatibility, careful consideration of in house versus outsourcing to develop new IT products (Bhoola, 2015, Spalek, 2014, Gingnell et al., 2014, and Cârstea, 2014).

14- Lessons learned discussions at the IT project completion are advised to build knowledge for better estimation and overall performing in future projects (Bhoola, 2015).

15- Human resources should not be ignored, as is the most important IT project management key success factor, as explained by Bhoola (2015), Spalek (2014), Gingnell et al. (2014), and Cârstea (2014). Also, the authors pointed out leadership and other competencies must be developed through applicable training, reasonable personnel policies, and a good rewarding system.

\section{Implications}

The key success factors highlighted by the articles studied provided direction to the organizations on the areas where they should focus more attention to strength their ability to effectively handle IT projects, either by recruiting and retaining talented project managers or increasing the knowledge of their current staff by formalized PM training and certifications, such as the Project Manager Professional (PMP).

\section{Limitations of the Study}

Since the study presents the trends in IT PM during the last three years, its limitations are associated to the individual limitations of each studied article and the amount of articles selected. Even with these limitations, the results showed valuable data pointing the important areas where an organization must focus their attention to improve their performance in managing IT projects.

\section{Future Work}

The study did not include research in countries such as Canada, Central and Latin America, Africa, and Oceania since EbscoHost did not show any within the last three years. It would be interesting to see if by adding those countries in a future study, the results would differ. Also, it is recommended to develop a questionnaire based on the 
results of this study and collect data through an international PM association, such as PMI, so that its results can be compared to the ones presented on this study.

\section{REFERENCES}

“information technology, n.” Business Dictionary, 2016, Web. 26 April, 2016. http://www.businessdictionary.com/definition/information-technology-IT.html\#ixzz46znvA5YA

“trend, n.” Merriam-Webster, 2016, Web. 26 April, 2016. http://www.merriam-webster.com/thesaurus/trend

Bhoola, V. (2015). Impact of Project Success Factors in Managing Software Projects in India: An Empirical Analysis. Business Perspectives \& Research, 3(2), 109-125. doi:10.1177/2278533715578555

Braun, G. (2014). Audit's Role in IT Project Success. Internal Auditor, 71(1), 67-69.

Capterra (2015). Capterra Project Management Blog: Fourteen Surprising Project Management Statistics. Arlington, VA: Capterra, Inc. Retrieved April 26, 2016, from http://blog.capterra.com/surprising-project-managementstatistics/

Cârstea, C. (2014). IT Project Management - Cost, Time and Quality. Economy Transdisciplinarity Cognition, $17(1), 28-34$.

Data Catalog (2016). Information Technology Project Portfolio. State of Connecticut: Data.gov. Retrieved April 26, 2016, from https://catalog.data.gov/dataset/information-technology-project-portfolio

Dutta, S., Geiger, T., \& Lanvin, B. (2015). The global information technology report 2015. World Economic Forum (Geneva). Retrieved April 26, 2016 from http://www3.weforum.org/docs/WEF_Global_IT_Report_2015.pdf

Fulk, H. K., Kwun, O., \& Alijani, G. S. (2013). Scapegoating Humans, Scapegoating Technologies: Examining Another Side of Information Systems Project Control. Academy Of Information \& Management Sciences Journal, 16(2), 31-48.

Gingnell, L., Franke, U., Lagerström, R., Ericsson, E., \& Lilliesköld, J. (2014). Quantifying Success Factors for IT Projects-An Expert-Based Bayesian Model. Information Systems Management, 31(1), 21-36. doi:10.1080/10580530.2014.854033

Gray, C. F., \& Larson, E. W. (2009). Administración de Proyectos, Cuarta Edición (4/E). Mexico, D. F.: McGrawHill Companies, Inc.

Haron, H., Gui, A., \& Lenny, M. (2014). Factors Influencing Information Technology Project Success: A Case of University Information Systems Development Division of Bina Nusantra. International Journal Of Organizational Innovation, 755-65.

Holgeid, K., \& Thompson, M. (2013). A reflection on why large public projects fail: The Governance of LargeScale Projects - Linking Citizens and the State. The Hertie School of Governance and the Journal for Political Consulting Advice (May 2013).

Jacobs, F. R., \& Chase, R. B. (2010). Operations and Supply Management: The Core, Second Edition, (2/E). New York, NY: The McGraw-Hill Companies, Inc. 
Jiang, J. J., Chang, J. T., Chen, H., Wang, E. G., \& Klein, G. (2014). Achieving IT Program Goals with Integrative Conflict Management. Journal Of Management Information Systems, 31(1), 79-106. doi:10.2753/MIS0742-1222310104

Kateb, G. A., Swies, R., Obeidat, B., Taisir, M., \& Maqableh, M. (2015). An Investigation on the Critical Factors of Information System Implementation in Jordanian Information Technology Companies. European Journal of Business and Management, 7(36). ISSN: 12222.2839

Keil, M., Smith, H. J., Iacovou, C. L., \& Thompson, R. L. (2014). The Dynamics of IT Project Status Reporting: A Self-Reinforcing Cycle of Distrust. Journal Of The Association For Information Systems, 15(12), 879-912.

Mastrogiacomo, S., Missonier, S., \& Bonazzi, R. (2014). Talk Before It's Too Late: Reconsidering the Role of Conversation in Information Systems Project Management. Journal Of Management Information Systems, 31(1), 44-78. doi:10.2753/MIS0742-1222310103

Nelson, R. R., \& Morris, M. G. (2014). IT Project Estimation: Contemporary Practices and Management Guidelines. MIS Quarterly Executive, 13(1), 15-30.

Obeidat, M., \& North, M. M. (2014). A Comparative Review of Information Technology Project Management in Private and Public Sector Organizations. International Management Review, 10(1), 55-62.

Obeidat, R. (2016). Managing Requirement Changes in Health Informatics Projects. International Management Review, 12(1), 39-51.

Paul, J. and Gupta, P. (2014). Process and intensity of internationalization of IT firms - Evidence from India. International Business Review, 23(3), 594-603.

Project Management Institute (2016). What is Project Management? Project Management Institute. Retrieved April 26, 2016, from http://www.pmi.org/en/About-Us/About-Us-What-is-Project-Management.aspx

Project Management Institute. (2013). A guide to the project management body of knowledge: PMBOK® guide, Fifth Edition (5/E). Newtown Square, Pa: Project Management Institute.

Rivera-Ruiz, I. \& Ferrer-Moreno, E. (2015). The relationship between strategic leadership, human IT infrastructure, project management, project success and firm performance, International Journal of Information, Business, and Management, 7(2).

Spalek, S. (2014). Finding a New Way to Increase Project Management Efficiency in Terms of Time Reduction. Engineering Economics, 25(5), 538-548. doi:10.5755/j01.ee.25.5.8419

Standish Group (2009). The CHAOS summary 2009. Retrieved on April 26, 2016 from https://www.classes.cs.uchicago.edu/archive/2014/fall/512101/required.reading/Standish.Group.Chaos.2009.pdf

Tuzcu, A., \& Esatoglu, N. (2011). Factors of Success in Information Technology Projects: Evidence from capital of Turkey, Ankara. Problems and Perspectives In Management, 9(2).

Wilfong, J. D. (2014). Organizational culture and information technology (IT) project success and failure factors: A mixed-methods study using the competing values framework and schein's three levels approach (Order No. 3628342). Available from ProQuest Dissertations \& Theses Global. (1559962047). Retrieved from http://search.proquest.com/docview/1559962047?accountid=44825 